\title{
Curriculum Reform at Tertiary Level as Key to Graduate Employability and Entrepreneurship in Lesotho
}

\author{
T. Mukurunge, N. Tlali \\ Limkokwing University of Creative Technology, Maseru, Lesotho
}

\begin{abstract}
The curriculum in Lesotho at tertiary level does not adequately prepare graduates for the employment world, nor for self-made business people. The main emphasis is theoretical and academic excellence rather than for production in industry or for empowerment with entrepreneurial skills. This is a problem because Lesotho does not have an industrial power base for the economy to employ a big number of tertiary graduates. The industries that offer employment to citizens are mainly the Chinese-owned textile industries and taxi/transport industry, or the South African mines and farms which require cheap labour and not tertiary graduates. Lesotho therefore requires an education that produces graduates who can create employment for other primarily or highly skilled technocrats who will be able to be employed above the level of mere labourers in the sophisticated economy of South Africa. This study therefore sought to establish what the Ministry of Education and tertiary institutions are doing about this scenario, whether they have plans for curriculum review that will be aligned towards producing entrepreneurs and technocrats for the economic development of Lesotho. This research will benefit the authorities responsible for development through small businesses, the employment sector, as well as tertiary institutions in curriculum review.
\end{abstract}

Keywords: curriculum, curriculum review, entrepreneurship, tertiary institutions, technocrats

Curriculum is a planned and guided learning experiences carried out in the institution for the purpose of living a useful and productive life in our contemporary society today (Ogwu, Omeje, \& Nwokenna, 2014, p. 44). Graduate employability means that higher education alumni have developed the capacity to obtain and create work (Kinash, 2015, p. 1). Furthermore, employability means that institutions and employers have supported the student knowledge, skills, attributes, reflective disposition, and identity that graduates need to succeed in the workforce (Hinchliffe \& Jolly, 2011; Holmes, 2013; Knight \& Yorke, 2004; Yorke, 2006; Yorke \& Knight, 2006 in Kinash, 2015, p. 1). Ogwu et al. (2014, p. 44) writing about the situation in Nigeria which is applicable to Lesotho said that the academic bias of curricula has been blamed in many countries for divorcing education from the world of work. Because of this academic bias, people who would normally have gone into some productive activity turn to fruitless search for white-collar employment and most countries' productive sectors can no longer support the expansion of white-collar employment (Ogwu et al., 2014, p. 44). The academic type of curricula in this case, caters for the needs of a small minority who are likely to end up in

Corresponding author: T. Mukurunge, Master of Arts in Media and Communication Studies, Faculty of Communication Media and Broadcast, Limkokwing University of Creative Technology, Maseru, Lesotho; research fields: education, science \& technology, social sciences, media \& journalism, human rights.

N. Tlali, Master of Science in Sociology, Faculty of Communication Media and Broadcast, Limkokwing University of Creative Technology, Maseru, Lesotho; research fields: sociology, journalism, science \& technology, education, human rights. 
professional jobs (Ogwu et al., 2014, p. 44). It therefore is in the light of this observation that this study sees the need to examine the structural reforms in Lesotho curriculum in order to determine a way forward.

Entrepreneurship is the sacrifice by an individual to start their own business enterprise and is classified into many types (e.g. agricultural, social, global, large company, scalable start-up, trading, and industrial) (Baker, 2015, p. 4).

Most education systems in the formerly colonized developing and underdeveloped economies reflect a pattern whereby citizens are geared to acquire an education that would neatly cut them out for the world of employment, primarily as civil servants, rather than empowering them with skills to enable them to start their own businesses. This is detrimental to economies such as that of Lesotho where industry is very minimal and most university graduates cannot secure employment in the country, because the civil service cannot absorb everyone, unless they venture and melt into the well-established economy of South Africa. Universities and other tertiary institutions in Lesotho should therefore seriously contemplate an education system that, on paper and practice, should emphasize a paradigm shift from a well-read bookish product to someone with the mindset to start a business and employ others.

In a report to the United Nations (UN) General Assembly, the UN Secretary General presented that entrepreneurship (the activity of setting up a business or businesses, taking on financial risks in the hope of profit) has offered the opportunity to many of the world's poor to earn a sustainable livelihood. Entrepreneurship represents a sizeable engine of decent employment generation and can provide an important contribution to sustainable development by creating jobs and driving the economic growth and innovation, fostering local economic development, improving social conditions, and contributing to addressing environmental challenges (United Nations, 2014, p. 1).

European Commission (2016, p. 2), in setting a skills agenda for Europe, wrote that skills are a pathway to employability and prosperity. With the right skills, people are equipped for good-quality jobs and can fulfil their potential as confident, active citizens. The European Commission (2016, p. 2) continued to write that in a fast-changing global economy, skills will to a great extent determine competitiveness and the capacity to drive innovation, and they are a pull factor for investment and a catalyst in the virtuous circle of job creation and growth and they are key to social cohesion.

UNEVOC (2013, p. 8) said that skills acquisition is necessary for industrial development and there is need to accord full and committed attention to Technical Vocational Education and Training (TVET), for the realization of economic and industrial development, and to provide a basis for maintaining competitive advantage. UNEVOC (2013, p. 8) emphasized on the need to revitalize and promote regional integration, assuring that young people are equipped with social and market-related skills which will enable them to be well-integrated young adults as well as competitive at national, sub-regional, and global levels. In the new global economy, young people need to acquire more than just basic education, and the current rate of globalization and regional integration should influence curricula (UNEVOC, 2013, p. 8). The UNEVOC (2013, p. 8) document went on to say that investing in education and skills development for young people should go beyond increasing basic literacy rates to assure dynamic, multifaceted knowledge-building at higher and tertiary levels, including TVET, but should go a long way in preparing young people for the evolving labour market.

The Lesotho Council on Higher Education (CHE) policy states that its aim is to ensure that Lesotho's higher education system produces graduates with the knowledge, skills, and values to contribute to the nation's 
development, as well as the capacity to respond to challenges and exploit opportunities that will arise in the future. For this to happen, there is a need for Basotho to forge a shared understanding of the shape, size, and purpose of the higher education system that is required to meet the nation's needs (Council on Higher Education, 2013, p. x).

It is in line with the above observations that this study would like to establish the position of the Lesotho education system at tertiary level with regards to its alignment to these new trends of graduate entrepreneurship, employment creation and matching of new market trends.

\section{Statement of the Problem}

The education system in Lesotho suffers the colonial legacy of educating people for the purpose of acquiring an education that qualifies the graduates to be mere employees, particularly in the civil service, rather than the acquisition of skills that will lead graduates to create jobs for themselves and for others. This education system should undergo a paradigm shift in order to create graduate entrepreneurs who will create jobs for themselves and others thereby driving economic development at national level.

\section{Study Objectives}

This study sought to establish how much tertiary institutions are driving the agenda of imparting entrepreneurial skills in their graduates for the creation of a business-minded generation as well as to influence tertiary education policy makers to shift towards training tertiary students to be skilled in job creation and drive national economic development through tertiary graduates' entrepreneurial skills.

\section{Research Questions}

(1) What is the current higher education policy for Lesotho on the training of entrepreneurial skills?

(2) To what extent is entrepreneurship being imparted and inculcated in tertiary students in Lesotho?

(3) How effective are graduates of entrepreneurship in employability and job creation in Lesotho towards the development of the national economy?

\section{Theoretical Framework}

The study is informed by the theory of curriculum. Curriculum is Greek in origin meaning race course but in formal education stands for academic programme provided in schools and colleges, giving meaning, structure, and extension to the syllabus, covering the peripheral supplements for a complete course for skills acquisition (Rani, 2014, p. 869).

Rani (2014, p. 871) wrote that curriculum is an educational path that implies which goals and objectives should be achieved, which topic should be covered, and which method is to be used for learning, teaching, and evaluation. It is the totality of the techniques and technology of educational practices that comprises the content and conceptualization, transaction methodology and evaluation that help the wards have continuing consciousness (Rani, 2014, p. 871).

\section{Literature Review}

Writing about the relevance of entrepreneurship studies in institutions of higher learning in the United Kingdom, Moreland $(2003$, p. 2) said that higher education should take entrepreneurship in its various forms more seriously because single-person enterprises have got an overwhelming importance to the UK economy 
and such enterprises usually create personal employment for graduates who start the businesses as well as for others.

Watts (2006, p. 3) wrote that higher education's focus on enhancing students' employability can actually reinforce rather than threaten traditional academic values although it will require organizational change within higher education.

Rahimi, Amini, and Jahanbani (2015) wrote that significant quantitative growth in higher education and the educational mission of universities on the one hand, and neglecting to promote innovative and entrepreneurial thoughts among students on the other hand have caused a significant proportion of the unemployed and job seekers in Iran and these unemployed are holders of university qualifications. This rings true of the scenario in Lesotho which has seen the number of universities rising from one (the National University of Lesotho) by 2008 to three by 2015 (with the introduction of two private universities: Limkokwing University of Creative Technology in 2008 and Botho University in 2015).

Rahimi et al. (2015) cited one of the roots for this problem being the disharmony between university graduates and the needs of the labour market and also the fact that most academic courses, especially in humanities, are purely theoretical and there has not been an attempt to use them more practically. University graduates, therefore, are mainly in search of work in governmental agencies and organizations and are less inclined to create employment (Kowsari \& Norrouzadeh, 2009 as cited by Rahimi et al., 2015).

Onyesom and Uwaifo (2013, p. 141) on the merits of entrepreneurship education for Nigeria wrote that entrepreneurship education is a potent tool in the fight against youth unemployment. They also identify that the system of education in Nigeria has been structured in such a way that it is employment oriented to the detriment of employment generation by the individuals and that the long-term effects are the rise in unemployment for the youth (Onyesom \& Uwaifo, 2013, p. 141).

In economies characterized by low labor demand and high rates of youth unemployment, entrepreneurship training has the potential to enable youth to gain skills and create their own jobs (Premand, Brodmann, Almeida, Grun, \& Barouni, 2012, p. 3).

Humburg, van der Velden, and Verhagen (2013, p. 50) wrote that skills graduates are expected to display in the 21 st century are: professional expertise, general academic skills, innovative/creative skills, strategic/organizational skills, interpersonal skills, and commercial/entrepreneurial skills. The teaching of such skills is scarce in Lesotho at the moment due to the emphasis on theory by the current curriculum.

Garwe (2014, p. 2) wrote that most literature acknowledges the definition of graduate employability given by Yorke (2006), who described it as a set of achievements - skills, understandings, and personal attributes - that makes graduates more likely to gain employment and be successful in their chosen occupations, which benefit themselves, the workforce, the community, and the economy. Garwe (2014, p. 2) went on to cite Bunt et al. (2005) who referred to them as skills that cut horizontally across all industries and vertically across all jobs from entry level to chief executive officer. Employers regard employability as "work readiness", whereby the graduate should possess the skills, knowledge, attitudes, and commercial understanding that will enable him/her to make productive contributions to organizational objectives soon after assumption of duty (Mason et al., 2006 in Garwe, 2014, p. 2).

The British Council (2014, p. 6) on quality of delivery in institutions of higher learning across Sub-Saharan Africa said that their products cannot hold their own in industry to contribute to the economic development of their countries to the extent that the only place they can be employed is back in those 
institutions as lecturers. This then makes it a vicious cycle of recycling mediocrity because the same products will continually be non-productive for industry and national development.

Governments, especially in developing countries where education policies are externally driven, seem to require higher education institutions such as universities to shift from their traditional role of educating and assume a new role of training in order to produce adaptable and globally competitive workforce (Raselimo, 2013). Raselimo aptly summarises the situation of tertiary education in Lesotho where traditionally the focus has always been in providing theoretical knowledge rather than life skills training to produce graduates with the knowledge how to set up and run businesses profitably.

\section{Methodology}

The methodology for this study involved a mix of secondary and primary data collection through interviewing key informants from the relevant sectors. Primary data are data that are collected for the specific research problem at hand, using procedures that fit the research problem best (Hox \& Boeije, 2005, p. 1). On every occasion that primary data are collected, new data are added to the existing store of social knowledge and this material created by other researchers is available for reuse by the general research community as secondary data (Hox \& Boeije, 2005, p. 1). This study used in-depth interviews with university curriculum and policy makers and lecturers and distributed questionnaires for completion by graduates. Secondary sources were analyzed to determine the policy by education authorities at national level as well as the Council on Higher Education as the authority responsible for quality assurance. Findings were analyzed qualitatively.

\section{Findings}

The Council on Higher Education (2013, p. 12) policy document stated that the overarching aim of its policy is to ensure that Lesotho's higher education system produces graduates with the knowledge, skills, and values to contribute to the nation's development, as well as the capacity to respond to challenges and exploit opportunities that will arise in the future. Policies are also articulated for enhancing students' preparedness for the working world after graduation, including greater use of work attachments and innovative ways of promoting and supporting entrepreneurship among students (Council on Higher Education, 2013, p. 14).

A manager responsible for internship and entrepreneurship at one of the tertiary institutions spelt out that Lesotho does not have a policy document specific to entrepreneurship teaching at tertiary level. He elaborated that the setting up of the entrepreneurship platform at his work place is an initiative totally driven from within the university and inspired by the UNDP and the UN Sustainable Development Goals (SDGs). He also explained that his institution is unique in Lesotho for pioneering the emphasis on entrepreneurial initiative at university level and tries to relieve the nation of the pressure of unemployment.

Tertiary graduates gave responses that showed mixed feelings towards the approach towards entrepreneurship by their institutions. One respondent said that entrepreneurial studies in university took her further than mere passing and completing her studies because the institution empowered them by creating a platform whereby students would be allowed to come up with new ideas and inventions and got mentorship in creating viable business plans. She also said her university has got the platform where students who wanted to start their own businesses would, instead of going into the field for internship, remain on campus attached to the Entrepreneurship Accelerated Platform where they are groomed from the initial stage of drafting a business plan, get assistance with starting and launching projects of their own, and pitch to prospective clients with the 
university providing financial and technical support. The university also goes out to solicit for business for the young companies from outside.

One other respondent said that his university, whose ideology is based on creativity, changed to ground his mindset in innovative creativity. He went on to say the university gave him a philosophy that enabled him to free his mind from deficit to asset-based thinking. This student went on to venture into television production and the end result was for him producing a television series he is currently polishing for Lesotho Television.

However, one student said that the university did a lot for him and his colleagues in developing their ideas into tangible business concepts but, regrettably, did not offer them any financial support.

The SBP (2008, p. 117) survey on Lesotho established that of people who had started business enterprises, when asked to rate the ease with which an individual is able to obtain advice on starting or running a business; $61 \%$ of respondents said that such advice was easy or very easy to obtain, while $20 \%$ said that it was difficult and $8 \%$ very difficult.

The SBP (2008, p. 118) survey went on to say that the majority of respondents relied on informal sources such as family (27\%), friends (23\%), and other business owners (22\%) rather than official sources of advice such as business development service providers or government agencies. Government agencies mentioned as sources of advice and support included the Ministry of Trade and Industry, Cooperatives and Marketing (MTICM), Basotho Enterprises Development Corporation (BEDCO), and Lesotho National Development Corporation (LNDC). Two respondents mentioned one stop shop in Maseru run by MTICM but none mentioned having learnt entrepreneurship in college or university.

The SBP (2008, p. 121) survey sought information on how small businesses thought government should assist in order to improve the environment for small businesses and established that larger and/or more sophisticated businesses identified a number of issues on which government might reasonably be expected to engage the smallest businesses in the sample tending to make some fairly unrealistic suggestions, which mainly involved accessing cash with very few strings attached. No one mentioned government support through establishment of entrepreneurial studies to empower them with the skills to develop business plans or teach them management of resources and finances in their new businesses. Access to finance was mentioned by $29 \%$ of businesses in the sample, and was by far the most frequently mentioned area in which businesses would like assistance (SBP, 2008, p. 121). These mentions however included a high proportion of requests for direct cash assistance from government, rather than mere constructive suggestions in respect of accessing loans and credit facilities.

One lecturer respondent from one of the universities in Lesotho said that the LNDC has got funds to assist emerging businesses at the ready. However, the challenge faced by the LNDC in the disbursement of these finances arises when it comes to the quality of business proposals presented by applicants. The lecturer went on to say that the LNDC is reluctant to finance poorly planned businesses as evidenced by the low-quality proposals. In response to this, one university graduate and prospective entrepreneur said that the LNDC seems to release funding for agriculture-related enterprises at the expense of the rest and protested its unfairness.

The UNDP (2015, p. 89) said that the Lesotho education system needs improvement so as to address the limited options in terms of entrepreneurship culture, soft and life skills, and creativity because out of the three universities in Lesotho, only one makes an effort to teach entrepreneurship to students from all faculties at associate degree level. Most Honors degree students do not enjoy this benefit and empowerment platform, however, from the same institution. The other institutions only offer entrepreneurship to students studying commerce and business studies. 
The UNDP $(2015$, p. 89) recommended that the government of Lesotho should facilitate integration of a broad range of skills in the curricula at different levels, and build capacity of teachers in the areas of critical thinking, ICT, entrepreneurship, life skills, creativity, and innovation.

\section{Analysis}

In light of the discoveries above, this study observes that the government of Lesotho, through the Ministry of Education as well as the Council on Higher Education, should put in place a solid policy to instigate the teaching of entrepreneurship and facilitate skills acquisition by all tertiary students so that graduate employability and the ability to start own businesses are enhanced. The current status whereby the initiative for the teaching of entrepreneurship is left to individual institutions is not ideal at all because other institutions will simply ignore the introduction of the teaching of these life skills courses because it comes with financial repercussions.

The government should regard this as an investment in the nation's future and weigh in with material support because the teaching of entrepreneurship and life skills needs resources such as industrial machinery and financial back-up in order for companies started by students to be sustainable. The only institution to offer entrepreneurship seriously to students in Lesotho has invested serious money in setting up office space from which students who set up companies can operate from and also provides the students with computers and internet connectivity in addition to providing a mentor from industry and introducing students to prospective investors. The government, through the Ministry of Small and Medium Enterprises should therefore contribute by providing financial support so that the businesses started by the students are launched properly and do not sink into oblivion as soon as the students and their projects are weaned by the university. It is impossible for the university to train and then provide funding for every prospective student entrepreneur.

The government and the responsible agencies can solicit help from the banking sector and ask them to intervene by providing loan facilities to entrepreneurial initiatives in order to ensure a long life for such initiatives. Otherwise even if the institutions of higher learning will have empowered the students with the requisite life skills, without financial back-up, the projects will sink into oblivion prematurely.

In order for students to have an early appreciation of entrepreneurship and life skills, it would be most ideal for policy makers to introduce practical subjects from high school into tertiary level so that students have production embedded in their psyche to replace the tradition of going to school, earn a good mark, attain a certificate, and look for a job. Such a mentality should be systematically replaced by the hunger to produce own businesses and employ others.

The government can also provide support for tertiary institutions in the form of specialists in implementing the teaching of entrepreneurship and life skills from institutions in South Africa and beyond to guide introduction and implementation in those areas of special need. Lesotho can follow the wisdom of other countries, such as Nigeria, in formulating national policy to inform the teaching of entrepreneurship and life skills in order to produce home-grown business people and employable graduates. For instance, the national policy on education introduced by the Federal Government of Nigeria states that the importance of tertiary education is to prepare young people for the job market; to have sustainable employment by enhancing technical skills and competence in a chosen field, and life skills such as problem solving and analytical skills, effective communication and literacy skills, interpersonal and team skills, etc. (Phillips Consulting, 2014, p. 4). 


\section{Recommendations}

This paper calls for a serious rethink of policy by the authorities responsible for curriculum formulation and implementation in Lesotho to inculcate entrepreneurial and life skills to enhance employability and job creation by graduates in Lesotho. A mere mention by the powers that are acknowledging the importance of impartation of life skills and entrepreneurial skills in tertiary students is not enough if there is no policy to systematically see this being implemented.

Institutions should also benchmark with institutions that are oriented towards entrepreneurship and life skills education rather than institutions that emphasize theory.

Government should also work closely with industry so as to solicit support for tertiary institutions for learning to be practical so that learning is oriented towards production.

\section{Conclusions}

Curriculum is a planned and guided learning experience carried out in the institution for the purpose of living a useful and productive life in our contemporary society today. Graduate employability means that higher education alumni have developed the capacity to obtain and create work. Entrepreneurship is classified into many types (e.g. agricultural, social, global, large company, scalable start-up, trading, and industrial). The education system in Lesotho suffers the colonial legacy of educating people for the purpose of acquiring an education that qualifies the graduates to be mere employees, particularly in the civil service, rather than the acquisition of skills that will lead graduates to create jobs for themselves and for others. This study sought to establish how much tertiary institutions are driving the agenda of imparting entrepreneurial skills in their graduates for the creation of a business-minded generation as well as to influence tertiary education policy makers to shift towards training tertiary students to be skilled in job creation and drive national economic development through tertiary graduates' entrepreneurial skills. The study is informed by the theory of curriculum. Significant quantitative growth in higher education and the educational mission of universities on the one hand, and neglecting to promote innovative and entrepreneurial thoughts among students on the other hand have caused a significant proportion of the unemployed and job seekers in Iran and these unemployed are holders of university qualifications. The methodology for this study involved a mix of secondary primary data collection through interviewing key informants from the relevant sectors. The Council on Higher Education (2013, p. 12) policy document stated that the overarching aim of its policy is to ensure that Lesotho's higher education system produces graduates with the knowledge, skills, and values to contribute to the nation's development, as well as the capacity to respond to challenges and exploit opportunities that will arise in the future. This study observes that the government of Lesotho, through the Ministry of Education as well as the Council on Higher Education, should put in place a solid policy to instigate the teaching of entrepreneurship and facilitate skills acquisition by all tertiary students so that graduate employability and the ability to start own businesses are enhanced. This paper calls for a serious rethink of policy by the authorities responsible for curriculum formulation and implementation in Lesotho to inculcate entrepreneurial and life skills to enhance employability and job creation by graduates in Lesotho.

\section{References}

Baker, M. (2015). Developing the capacity of middle-level tertiary education in preparing and nurturing young entrepreneurs in Sub-Saharan Africa. Retrieved from https://innovate.oired.vt.edu/wp-content/uploads/2015/09/BakerEntreprenEdFINAL.pdf 
British Council. (2014). Can higher education solve Africa's job crisis? Understanding graduate employability in Sub-Saharan Africa. Retrieved from https://www.britishcouncil.org/sites/default/files/graduate_employability_in_ssa_final-web.pdf

Council on Higher Education. (2013). Higher education policy for the Kingdom of Lesotho. Retrieved from http://www.che.ac.ls/ documents/CHE\%20Policy\%20(2013).pdf

European Commission. (2016). Communication from the commission to the European Parliament, the Council, the European Economic and Social Committee and the Committee of the Regions: A new skills agenda for Europe. Retrieved from https://eur-lex.europa.eu/legal-content/EN/TXT/?uri=CELEX:52016DC0381

Garwe, E. C. (2014). Holistic initiatives for enhancing graduate employability in Zimbabwe. Research in Higher Education Journal. Retrieved from https://files.eric.ed.gov/fulltext/EJ1064137.pdf

Hinchliffe, G., \& Jolly, A. (2011). Graduate identity and employability. British Educational Research Journal, 37(4), 563-584.

Holmes, L. (2013). Competing perspectives on graduate employability: Possession, position or process? Studies in Higher Education, 38(4), 1-17.

Hox, J. J., \& Boeije, H. R. (2005). Data collection, primary vs. secondary. Encyclopedia of Social Management, volume 1. Retrieved from www.joophox.net/publist/ESM_DCOL05.pdf

Humburg, M., van der Velden, R., \& Verhagen, A. (2013). Final report: The employability of higher education graduates: The employers' perspective. Retrieved from http://edz.bib.uni-mannheim.de/daten/edz-b/gdbk/14/bld/employability_higher_ed ucation_Final\%20report.pdf

Kinash, S. (2015). 8 ways to enhance your students' graduate employability. Retrieved from https://bond.edu.au/files/627/ $8 \% 20$ ways $\% 20$ to $\% 20$ enhance $\% 20$ your $\% 20$ students $\% 20$ graduate $\% 20$ employability.pdf

Knight, P., \& Yorke, M. (2004). Learning, curriculum and employability in higher education. London: Routledge Falmer.

Moreland, N. (2003). Entrepreneurship and higher education: An employability perspective. UK: Generic Centre, Learning and Teaching Support Network.

Ogwu, E. N., Omeje, M. O., \& Nwokenna, E. N. (2014). Structural curriculum reform and unemployment among youths in Nigeria: Implications for peace development. International Journal of Humanities Social Sciences and Education (IJHSSE), 1(12), 44-50.

Onyesom, M., \& Uwaifo, C. E. (2013). Reforming entrepreneurship education curriculum of Nigerian tertiary institutions for graduates empowerment. International Journal of Education Research, 1(12), 141-148.

Phillips Consulting. (2014). Education \& employability survey report. Retrieved from http://www.phillipsconsulting.net/files/ education_survey_report_mar2014.pdf

Premand, P., Brodmann, S., Almeida, R., Grun, R., \& Barouni, R. (2012). Entrepreneurship training and self-employment among university graduates: Evidence from a randomized trial in Tunisia. Retrieved from http://ftp.iza.org/dp7079.pdf

Rahimi, H., Amini, M., \& Jahanbani, F. (2015). The place of entrepreneurial curriculum components in higher education. International Journal of Academic Research in Business and Social Sciences, 5(9), 263-279.

Rani, T. A. (2014). Curriculum reform: Theory of curriculum-A starting or a final point of curriculum reform. Sociology Study, 4(10), 869-880.

Raselimo, M. (2013). Accreditation standards for higher education in Lesotho: Exploring issues of quality and relevance. Lesotho Social Science Review: A Journal of the Faculty of Social Sciences, National University of Lesotho, 33(1), 1-15.

SBP. (2008). The state of small enterprise in Lesotho. Retrieved from http://www.sbp.org.za/uploads/media/FINAL Lesotho_State_of_Small_Enterprise_Survey_23_10_08.pdf

UNDP. (2015). Lesotho national human development report: Leveraging the power of youth to promote human development. Retrieved from http://hdr.undp.org/sites/default/files/final_lesotho_high_res_single_pages.pdf

UNEVOC. (2013). UNESCO-UNEVOC regional forum: Advancing TVET for youth employability and sustainable development. Retrieved from http://www.unevoc.unesco.org/fileadmin/up/africa_regional_forum_meeting_report_2013online.pdf

United Nations. (2014). Entrepreneurship for development-Report of the secretary-general. Retrieved from http://unctad.org/ meetings/en/SessionalDocuments/a69d320_en.pdf

Watts, A. G. (2006). Career development learning and employability. The Higher Education Academy. Retrieved from https://www.qualityresearchinternational.com/esecttools/esectpubs/watts\%20career.pdf

Yorke, M. (2006). Employability in higher education: What it is-what it is not. York, UK: Higher Education Academy. 